\title{
Multimodal Stylistics in Graphic Novel: Understanding the Visual Language Syntax in Art Spiegelman's Maus
}

Dr. Baishalee Rajkhowa

Assistant Professor, Department of English, Royal School of Languages, Royal Global University, Assam, India

Corresponding Author: Dr. Baishalee Rajkhowa, E-mail: baishaleeraj@gmail.com

\section{ARTICLE INFORMATION}

Received: November 14, 2020

Accepted: January 20, 2021

Volume: 4

Issue: 1

DOI: 10.32996/ijllt.2021.4.1.5

\section{KEYWORDS}

Multimodality, visual language syntax, images, graphic narration, monochrome

\section{ABSTRACT}

Maus (2003) by Art Spiegelman is a graphic novel of unfolding his father, Vladek's, World War II ordeal and how he survived the holocaust. It is a gripping story of Spiegelman's own parents' experience in Poland during 1930s when Nazis invaded and persecuted the Jews. With a broken language, gaps in communication and visual strategy, Maus takes the readers across Europe unravelling the experiences of World War II and the Nazi Concentration camps. The characters are depicted as anthromorphic animals; the Nazis as cats, the Jews as mice and the Polish as pigs. It can be named as an autobiography or a memoir featuring a metareferential frame story with an author as narrator (Art) who tells his father (Vladek) that he wishes to write a comic book and so incited him to tell about " his life in Poland and the war" (Spiegelman, 2003). A graphic novel is written in a comic strip format which uses a combination of text and illustration in order to tell a story. The linguistic elements in a graphic narration are important as words and images cannot be analysed in similar terms. Multimodal stylistics represents this in the light of lexical and grammatical aspects of the verbal language. Maus (2003) represents a story of the holocaust and the traumatic experiences of Vladek. It is a heteroglossic text with the presence of foreign languages and an authorial voice. The novel not only gives a different meaning but also an altogether different perspective to the verbal and visual significance.

\section{Introduction}

Maus by Art Spiegelman (2003), is a graphic novel unfolding his father, Vladek's, World War II ordeal and how he survived the holocaust. It is a gripping story of Spiegelman's own parents' experience in Poland during 1930s when the Nazis invaded and persecuted the Jews. The novel describes the psyche of young Art and how it had affected him and its many survivors. With a broken language, gaps in communication and a visual strategy, Maus tries to take the readers across Europe unravelling the experiences of World War II and the Nazi Concentration camps.

As a graphic novel, Maus (Spiegelman, 2003) is written in a comic strip format and uses a combination of text and illustration in order to tell a story. The linguistic elements in a graphic narration are important as words and images cannot be analysed in similar terms. According to Nina Norgaard (2009), all communication and texts are multimodal involving visual effects along with typography and wording, colour, layout and visual images. In Maus (Spiegelman, 2003), the words are read as visual elements and images in language. There are basically two modes of operation in the novel: verbal and the visual. The characters are depicted as anthromorphic animals; the Nazis as cats, the Jews as mice and the Polish as pigs. It can be named as an autobiography or a memoir featuring a metareferential frame story with an author as narrator (Art) who tells his father (Vladek) that he wishes to write a comic book and so incited him to tell about " his life in Poland and the war" (Spiegelman, 2003). Maus (2003) represents a story of the holocaust and the traumatic experiences of Vladek. It is a heteroglossic text with the presence of foreign languages and an authorial voice. The paper attempts to study multimodal stylistics through the use of visual language syntax.

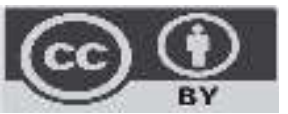

Published by Al-Kindi Center for Research and Development. Copyright (c) the author(s). This open access article is distributed under a Creative Commons Attribution (CC-BY) 4.0 license 


\section{Literature Review}

There has been a lot of insightful research work on the various aspects of the use of visual images, multimodality and linguistic elements related to the study. For example, Cohn, N (2013) explains this use of words and images as visual language syntax which leads to the structural organisation of "sequential images" in a graphic novel.

According to Clark and McNeill $(1992,2000)$, comics are written in a visual language; the same way that novels and magazines are written in a written language. Bramlett (2012) expressed that one of the guiding principles of linguistics is that people use different kinds of languages in different social situations depending upon the person's identity, topics, situation or purpose.

Kress and Van Leeuwen (1996, 2002), O' Toole (1994), O'Halloran, Baldry and Thibault (2005), and Bateman (2008) have done extensive research on the lines where thinking goes beyond words. According to them, the creative insights relate to the inner speech which further translates into language.

Miodrag (2013) provides critical insights to the various claims that there is an urgent need of a reappraisal of the linguistic elements within comics, whose importance can be more than the visual elements. Scanlon (2015) examined three ways in which Hannah's comics can be analysed: "Language in Comics", "Comics as Language" and" Images as Language".

According to Van Leeuwen (2006) and Norgaard (2009), the visual aspects of the verbal language have been further developed by on the use of italics, boldface and majuscules to create meanings for words. It provides the researcher with a methodology and terminology to be consistent while handling the different modes of multimodal meaning. Kress and Van Leeuwen (1996) state that visual images construct 'ideational' meanings through the representation of the participants, the processes involved and the circumstances.

\section{Methodology}

This paper follows the Theory of Multimodal Stylistics, Theory of Language, Theory of Generative Grammar and the Theory of Visual Language Syntax in order to unravel the topic under consideration.

Multimodal stylistics represents a systematic descriptive 'grammar' of all the semiotic modes developed for the mode of wording which represents the lexical and grammatical aspects of verbal language. Meaning beyond the images has aptly been described by Halliday (2009) in his Theory of Systemic Functional Linguistics, where a text is analysed on two levels: formal level and situational- context level and this has been carried forward by other researchers. Topography deals with the 'meaning-making' of the visual- side of the verbal language. According to the semiotic principles, the meanings are created by the visual side of the language. The analysis of the verbal and the visual through the images in Maus help to express the ideational, interpersonal and compositional (Halliday's 'texual').

In linguistics, syntax analyses the formation of words and phrases into sentences and also the structural organization of the meaningful units of a language into combined sentences. Visual language syntax is therefore the study of the structural organization of a sequence of images.

Generative grammar is a linguistic theory that regards grammar as a system of rules that generates exactly those combinations of words that form grammatical sentences in a given language. The theory also makes Chomsky to reject ungrammatical constructions. One can understand a speaker's competence by understanding his performance.

'Langue', according to Saussure comprises of all aspects and features of a language or 'the sum of word-images stored in the minds of the individuals'. The term 'parole' implies the actual or the concrete art of speaking by an individual at a particular time and space. Saussure also defines language as a system of signs- the signifier(word or sound) and the signified (concept).

\section{Results and Discussion}

Words are essential tools used by individuals to communicate. In Linguistics and the Study of Comics, Frank Bramlett (2012), expressed that one of the guiding principles of linguistics is that people use different kinds of languages in different social situations depending upon the person's identity, topics, situation or purpose. In the process of communication, the characters in Maus (Spiegelman, 2003), seem to produce some kind of linguistic exaggeration and simplification. The lexicon used by the characters perform different intentional speech acts such as informing, declaring, questioning, persuading, directing and other paralinguistic features like intonation, emancipation, loudness as well as the temperaments represented by the various characters to convey meaning to the situation. In Maus, there are many interior monologues where the speaker in the very beginning of the narrative uses to vivify and organise cognition, sometime in the momentary adoption of a dual persona as self- addressing self as though addressing a different person when Vladek's wife, Anna commits suicide. Even the gestures and graphic symbols used 
by the characters seem to exhibit some kind of visual vocabulary which also seemed to show some kind of link between graphic narrative and language of the novel.

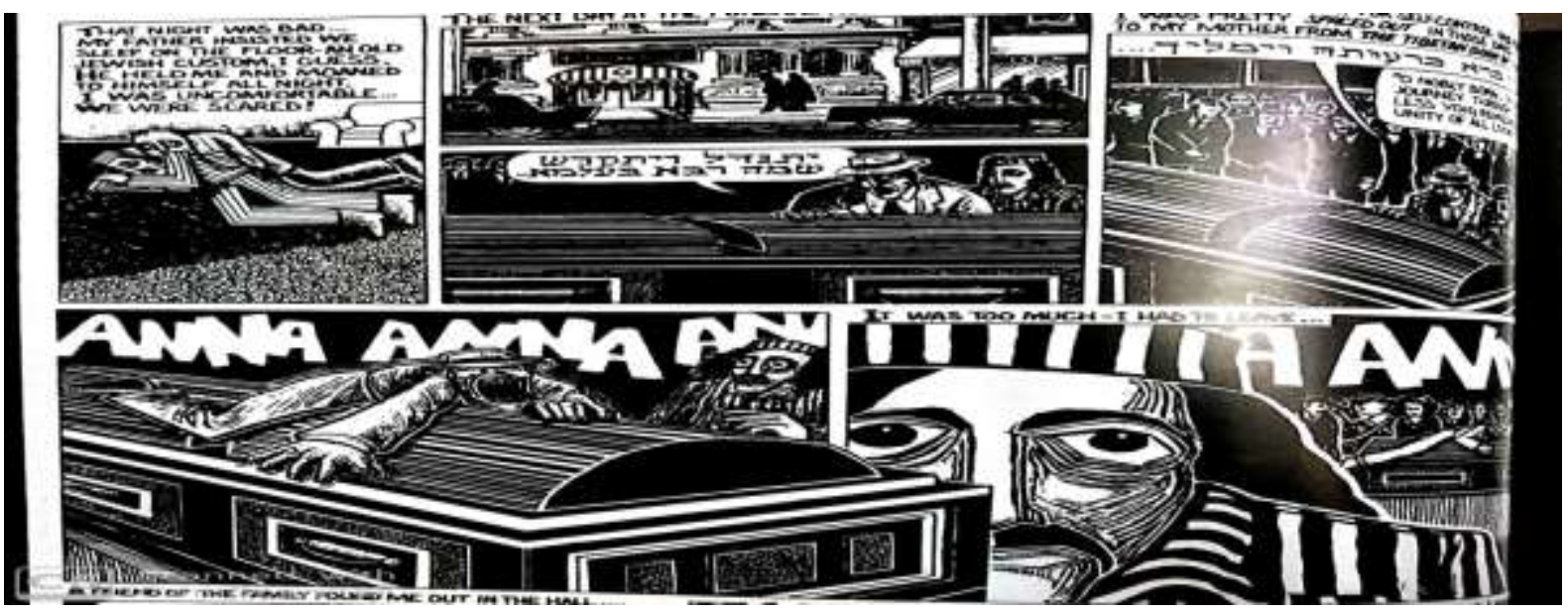

(Spiegelman 2003, p.104)

The aspects of the scene that has been particularly interesting as to how the panels have been drawn. The figures are drawn to show their domination of the space; the importance of each panel is an indication to show how the narrator is important in the story. In the scene we can see how words have been used to reflect the loss of Anna. Here the graphic salience can be considered as 'iconic' as it visually imitates the 'sonic salience' of someone shouting (Kress \& Van Leeuwen, 1996). There have been reflections on the use of various literary and linguistic critical theories which can be applied to graphical narratives. According to Miodrag (2013), the verbal and the visual interaction can be referred as a 'hybrid', because the term acknowledges that the new whole which is formed from the two new constitutes two new constituents which the ontologically separate entities. In visual images, modality can be represented through the background, detailing, colour saturation and differentiation, depth of articulation, light and shadow as well as the articulation of tone (Van Leeuwen, 2005). The absence of background setting will lead to low modality while the details in background setting can be considered as high modality. Through the comic form, the use of images helps us to identify the spatial environment of the images and how it effects the knowledge, experience, and narration of the graphic novel. Another way of linking the panels whether they are visual or verbal is through 'framing' and 'salience' (Kress and Van Leeuwen, 1996). 'Framing' pays more attention to the visual layout with the help of blank spaces, lines or colour, while 'salience' represents the most important element in a frame that stands out. The layout of Maus also aims to systematise the meaning created by the arrangement of the text and images in the spatial layout of the pages. According to Van Leeuwen (2005), the ways in which different layouts and images are linked to one another, whether verbal or visual, also help in the communication of the ideas. There is a cliché that a picture paints a thousand words where imagination is led by mighty images that the mind could ever conjure. In Maus, the words 'SLAM', 'SNRK', 'SNEAK, 'OW', 'BOOM', 'BANG', 'GROAN' and 'KPOK' are some sounds that rely on powerful visual and verbal elements which is also known as the "visual grammar" The words are typed instead of drawn but the same linguistic signifier would be read in an entirely different manner. These layouts also help in the construction of meaning in the texts.

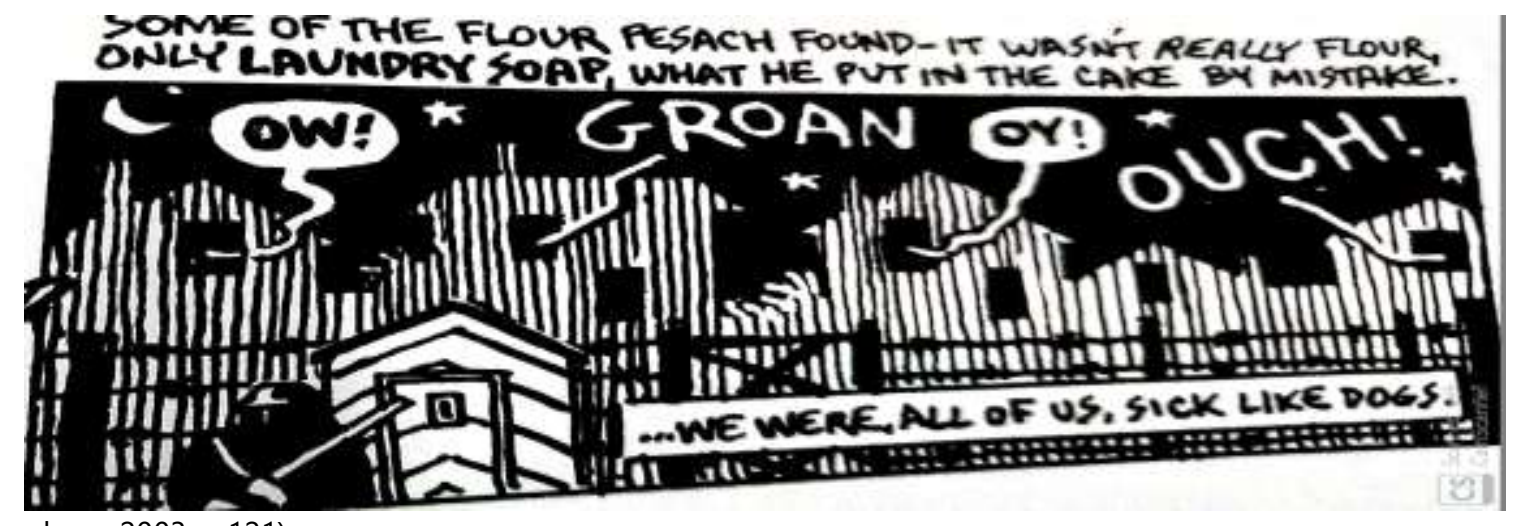

(Spiegelman 2003, p.121) 
While reading Maus, it not only gives a different meaning but also an altogether different perspective by applying a new lens to the verbal and visual significance. The speech balloons act both as an image as well as language simultaneously. The parallel frames denote logical connections through motivated signs and familiar conventions. Each panel acts as a word or a sentence. These layouts also help in the construction of the meanings in the texts. Comic author's writings about their medium have described the properties of comics as langue. Scott McCloud (1994) describes the properties governing the sequence of panels as its "grammar". There seems to be an intuitive link between comics and language in the minds of the creators, a belief shared by several researchers of language who discussed the properties of comics in a linguistic light.

Spiegelman (2003), used a lot of transitions within his work from action-to-action, subject to subject, scene - to - scene only to reveal the unity and fluidity between the pages. He uses these to identify the present as well as the flashbacks which take place in the novel many a time. The author uses the action-to-action transition so that it becomes easy for the reader to transgress from one frame to another (Spiegelman, 2003, p.52). When Vladek scolds Art for leaving the cigarette ashes on the floor and again in when Art and Vladek are checking the contents of the safe deposit box in the bank, he uses the same action-to-action transition (Spiegelman, 2003, p. 127)

Another transition used by the author is the subject-to-subject transition when Vladek and Anja are travelling in a train to the sanitorium (Spiegelman, 2003, p. 32). In one frame we find the mice (Jews) looking out of the window completely terrified. The audience is made to wait for the next frame to find out that the mice are staring at a large Nazi flag in the middle of the town. Only the subjects change though the scenes do not change.

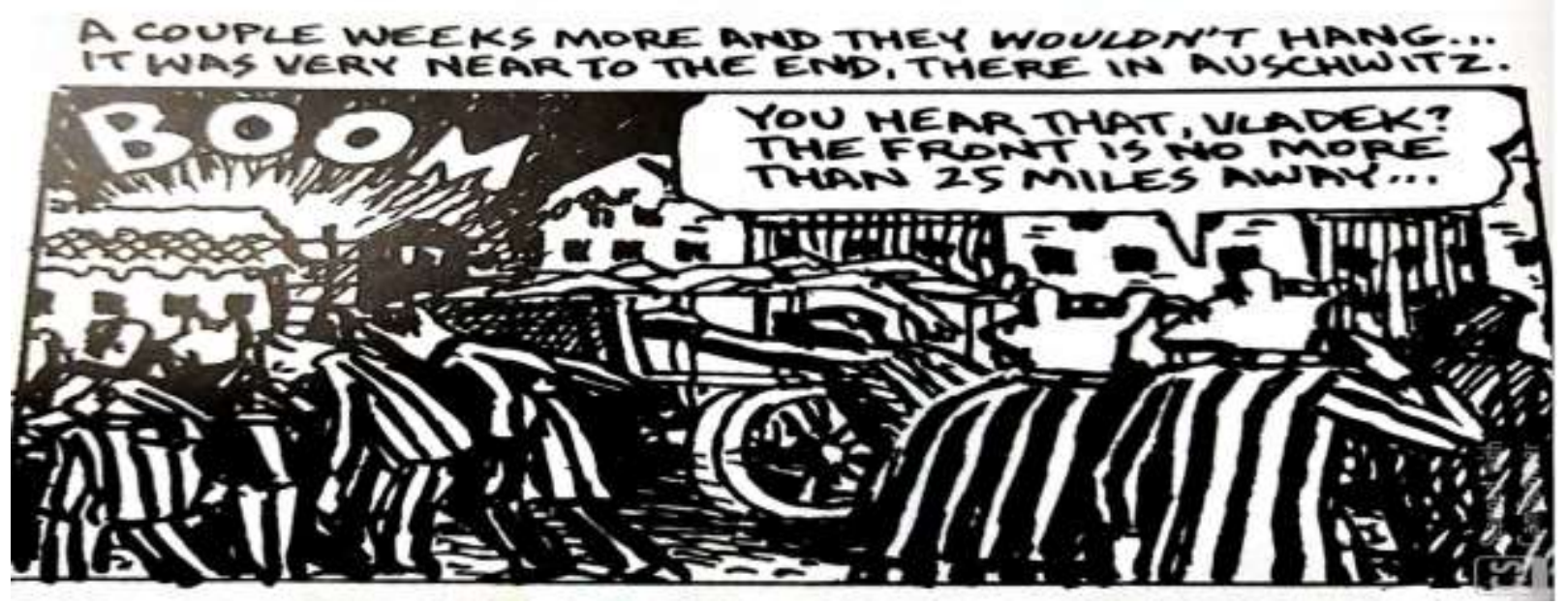

(Spiegelman 2003, p. 240)

Spiegelman (2003), tries to reveal the events in Poland, the war, Auschwitz through the narration. In the scene above we can see how sound is represented through the image of the word. These events take up the space of the panel in the foreground to show how Vladek is trying to tell a story of the crucial times. According to Gombrich (1961) and Randy Duncan (2012), the "language of art"' is the compositional make up of a single sentence. In Understanding Comics, McCloud (2014), expressed that there is a visual medium in comics which tries to captivate the readers by allowing them to use all their senses. By doing so, he coined a term for the new comic medium as "infinite canvas" where he tries to bend the presentation format into cartoons like experience and colourful childhood fascinations which simply whiz past the eyes of the readers.

In using monochrome in Maus, Baeterns (2011), feels that Spiegelman tried to unravel the story of the ordeal of Vladek in the holocaust and at the same time the autobiographical story of Art to learn his father's experiences in the war. In the field of graphic story- telling, colour is eventually associated with 'mass culture'. But it is however difficult to find out the real reasons for using monochrome in the novel. The graphic novel uses layers of black and white as it tries to portray it as a trauma novel. The author tried to equivocate between story-telling and drawing. The bright colours generally distract the audience from the narrative. Comics are generally published to retain the attention of the reader. The use of monochrome helps to redefine the relationship between the colour and the narrative device. Since the author emphasises on realism, he is more inclined towards the use of monochrome.

There is an indication that ellipsis should be used in condensed quotations. According to the MLA format (2009), when an ellipsis is placed after a sentence or at the beginning of the next, it has been noted that it is less used to indicate a pause but more often for an incomplete or unfinished thought. While analysing the visual images, multimodal theory has much to explain and 
from Van Leeuwen's (1996) "grammar and visual design", we can find out its experiential, interpersonal and compositional meanings. Modality, according to Norgaard (2010), is a semiotic resource "as how true" of "as how real" a given representation is understood.
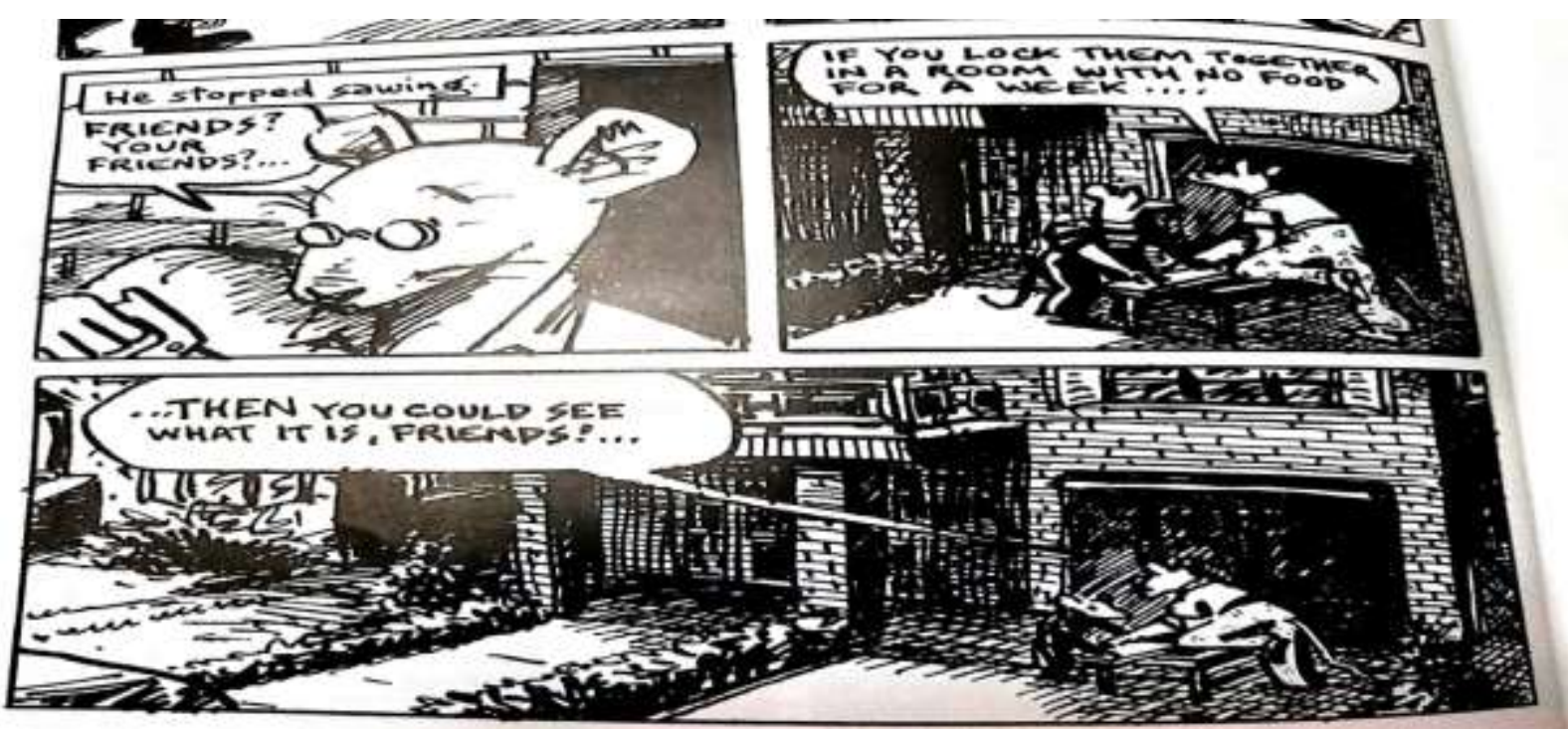

(Spiegelman 2003, p. 6)
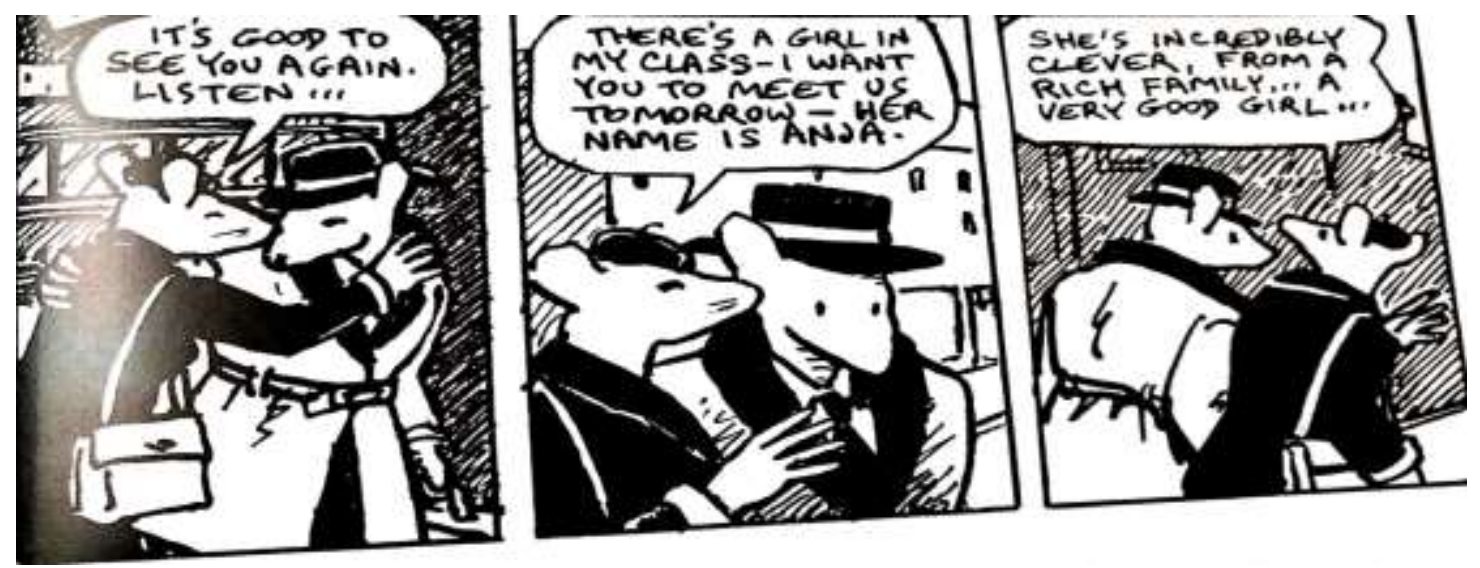

(Spiegelman 2003, p. 17)

The composition of the panels is mostly conservative with frames having the same size and uninterrupted gutters. The spaces between the frames known as "gutters", are more than empty spaces. The images in the text are rather dense and miniscule. The use of text in the speech bubbles, the sketches and images do not depend on the intrinsic story telling demanded by the narration. In the panels, the thoughts of the speakers seem to indicate some kind of internal silence. The 'gaps' are merely spaces between momentary panels in sequential strips in which the readers must make imaginative links to analyse the pictures. In the novel, there are pauses, turns, subversions and punch lines viz. "To die is easy. But you have to struggle for life" (Spiegelman, 2003, p.124) and again" Yes. Life always takes the side of life, and somehow the victims are blamed but it wasn't the BEST people who survived, nor did the best ones die. It was RANDOM!" (Spiegelman, 2003, p.205). There is use of alliterations viz. "He stopped sawing" (Spiegelman, 2003, p. 6), synonyms, homonyms and homophones by which registers are mixed and thereby plays with the minimal use of language by ungrammatically jumbling words together just allowing the strips to be left in their canny use of language. Though there is an action-to-action and scene-to- scene transitions in the narrative, a single subject feature in the distinct progressing of the actions. But there is also evidence of non-sequiturs in the novel which also point to the disconnected and fractured speech in the novel. The frames visually connect or disconnects the elements in a composition. It also plays an important role in the multimodal constructions in the novel. Frames not only helps to disconnect the general margins but also represents the semiotic concept at different levels and creates different kinds of meanings. 
The speech bubbles act as 'articulatory grammar' with dialogues and thoughts, narrative boxes and captions (Zanettins, 2008). They all set the spatial restrictions of the novel. All the panels, speech bubbles and the gutters, the shape and the size of the frames in the novel interact with one another thus creating a kind of message that needs to be decoded by the reader. Maus represents reality and the interplay of words and images is of paramount importance to describe it. Sentence fragments are common in the novel which masquerade as real sentences because they begin with a capital letter and end in a period. Fragment phrases are also an inherent part of the communication in between the characters. Interpersonal meaning is created by the positioning of the viewer and is analysed in terms of what Kress \& Van Leeuwen (1996) term as 'gaze', perspective and visual modality while compositional meaning is realised through information structure, inking, framing and salience. Mclntyre (2008) also tries to demonstrate how the visual and verbal aspects interact and helps to describe a systematic multimodal approach and explain a more 'comprehensive analysis' of the novel.
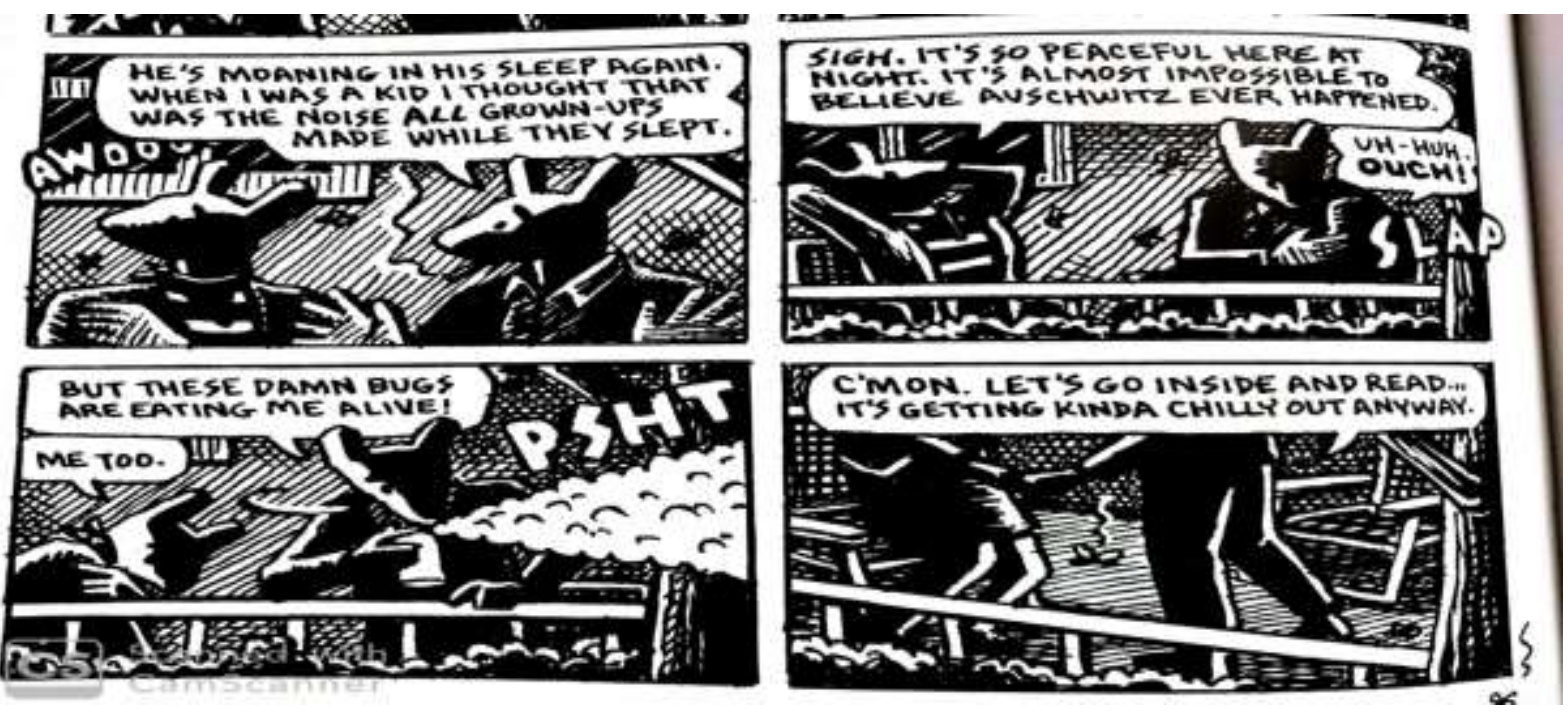

(Spiegelman, 2003, p. 233)

Maus demonstrates how language illustrates not only the power inherent in the language system (langue) but also distinguishes the visual from the verbal. The vocabulary is mostly that of Standard American with a number of Yiddish words.

\author{
"Get undressed! Leave your valuables! \\ Line up! Schnell!!" \\ 'Erverblutete" (Spiegelman, 2003, p.185)
}

Though the relationship between the verbal and the visual are indistinct in a graphic narrative, yet the linguistic signs often affect and is affected by the pictorial content, thus establishing a relationship between the verbal and the visual significance. Both the layout and typography in the novel are closely related. Van Peer (1993) explains that both layout and typography can be described under "typography" though both the terms have different modes of meaning. Typography represents the shape, colour, size and surface whereas layout is the overall spatial page design of the given text, including the visual elements, line spacing and alignment including the placing of the non- verbal elements, the graphic and the visual images, blank spaces and dots and so on. According to Baccolini and Zanettin (2008), "Language fails to convey the emotional distress associated with trauma; trauma resists language; and yet only a most accurate telling can begin to write trauma." Thus, Spiegelman (2003), used a particular medium to write a graphic novel. The layout of all the frames is packed with details and images are in monochrome to depict "trauma, fear and confusion" which are connected with the holocaust. The composition of each frame is so intense that they evoke the same kind of emotion in the readers. This use of visual grammar adds to the repressive and uncanny atmosphere of the survivors and of the holocaust. Parts of the novel take place in Poland in 1930s and 1940s. There has been evidences in the book where sentences are fragmented to show Vladek's use of broken English. Vladek was a Pole and his fragmented speech is seen in the images as the 'narrative' in the graphic novel. The also reflect the emotions of the protagonists through the dialogues.

\title{
5. Conclusion
}

In Maus, there is a network between the verbal and the pictorial where the juxtaposition, blending and balance takes place. McCloud (1994) ascribed these as montage, "where words are treated as integral parts of a picture." As we go through the novel, we find the images are a result of writing and drawing which are forms of human behaviour. We find the use of onomatopoeia 
as sequential images in the novel are part of the visual language. The non-vocal sounds images form the word-image interaction from the subtle to the forceful. Words are not enough in Maus to represent a genocide. The layout of the novel along with the detailed drawings may not have followed any chronological order but with the typography, it gives out a different meaning. Vladek's narration is constructed through a series of flashbacks where the events and characters were represented as flashbacks and depended on the off-screen voice of the narrator. The distinction between the different planes of narration through the panels gives a different verbal expression. The novel is simply classic with the use of monochrome colours to depict the fear and trauma of the aftermath.

The investigator makes an attempt to analyse multimodality through the use of visual language syntax in the novel. The aim of the study is to find out how the different use of the semiotic modes help in the construction of meaning in the text. The analysis of the novel brings forth the depiction of the fear, the trauma as well as the desperation of its characters which is well represented through the use of broken language, gaps in communication, speech bubbles, the monochrome colours, and the word images. The transition between the action-to-action, scene-to-scene and subject-to-subject in the novel helps to maintain the fluidity and the unity of the novel.

Wars can be a great loss to mankind and the aftermath of a war like the one mentioned here demonstrates the psychological and the physical trauma of the affected people. The study has highlighted the interrelationship between the verbal and the visual through the graphic narration which also help in the construction of meaning of the text. Since multimodal stylistics is a new field of research, future research can be based more on the modes and their interaction other than on the verbal and visual significance.

\section{References}

[1] Baccolini, R \& Zanettin, F. (2008). The language of trauma. Art Spiegelman's Maus and its Translations. Comics in Translation (F. Zanettin, Ed.). 99-132, St. Jerome Publishing.

[2] Baeterns, J. (2011). From Black and White to Colour and Black: What does it mean (not) to use colour?. www.jstor.org

[3] Baldry, A \& Thibault, P.J. (2006). Multimidal Transcription and Text Analysis. Equinox

[4] Bateman, J.A. (2008). Multimodality and Genre: A Foundation for the Systemic Analysis of Multimodal Documents. Palgrave Macmilan

[5] Bramlett, F. (Ed.). (2012). Linguistics and the Study of Comics. Palgrave Macmilan.

[6] Chomsky, N. (1957). Syntactic Structures. Mouton \& Co.

[7] Chomsky, N. (1968). Language and Mind. Harcourt Brace

[8] Cohn, N. (2013). The Visual Language of Comics: Introduction to the Structure and Cognition of Sequential Images. Bloomsbury Academic.

[9] Clark, H.H. (1996). Using Language. Cambridge University Press.

[10] Duncan, R. (2012). Image Functions: Shape and Color as Hermeneutic Images in Asterior Polyp. Routledge.

[11] Gombrich, E.H. (1961). Art and Illusion: A study in the Psychology of Pictorial Representation (2 ${ }^{\text {nd }}$ Revised ed.). Phaidon Press.

[12] Halliday, M.A.K. (1994). An Introduction to Functional Grammar (2 ${ }^{\text {nd }}$ ed.). Arnold.

[13] Hescher, A. (2016). Reading Graphic Novels: Genre and Narration. Walter de Gruyter.

[14] Kress, G \& Van Leeuwen, T. (2001). Multimodal discourse: The modes and media of Contemporary Communication. Arnold.

[15] Kress, G \& Van Leeuwen, T. (2006). Reading Images: The Grammar of Visual design. Routledge.

[16] MLA Handbook for Writers of Research Paper. (2009). $7^{\text {th }}$ Edition. Affiliated East-West Press Pvt. Ltd.

[17] McCloud, S. (1994). Understanding Comics: The Invisible Art. Herper Perennial.

[18] McIntyre, D. (2008). Integrating multimodal analysis and the stylistics of drama: a multimodal perspective on lan Mckellen's Richard III. Language and Literature, 17(4), 309-334.

[19] McNeil, D. (2000). Language and Gesture. Cambridge University Press.

[20] Miodrag, H. (2015). Comics and Language: Reimagining Critical Discourse on the Form. University Press of Mississippi.

[21] Nørgaard, N. (2009). The semiotics of typography in literary texts. A multimodal approach. Orbis litterarum, 64(2), 141-160.

[22] Norgaard, N. (2010). Multimodality: extending the stylistic tool kit (Busse, B \& McIntyre, D. (Eds). Language and Style. Palgrave

[23] O'Halloran, K.L. (2005). Mathematical Discourse: Language, Symbolism and Visual images. Continuum.

[24] O'Toole, M. (1994). The Language of Displayed Art. Leichester University Press.

[25] Saussure, Ferdinand de. (1983). Course in General Linguistics (C. Bally \& A. Sechehaye, Ed.) (R. Harris, Trans.). Open Court. (Original work published 1916)

[26] Scanlon, Molly J. (2015). Review of Comics and Language: Reimagining Critical Discourse on the Form. University Press of Mississippi.

[27] Spiegelman, A. (2003). Maus. Pantheon Books.

[28] Studdart-Kennedy, M. (1992). A Review of David McNeil (1992). Hand and Mind: What Gestures Reveal About Thought. University of Chicago Press.

[29] Van Leeuwen, T. (2005). Introducing Social Semiotics. Routledge.

[30] Van Peer, W. (1993). Typographic Foregrounding. Language and Literature, 2(1), 49-61. 